https://helda.helsinki.fi

\title{
Tensions and the Teacher's Role in Student Teacher Identity Development in Primary and Subject Teacher Curricula
}

\section{Anspal, Tiina}

2019-07-29

Anspal , T , Leijen , Ä \& Löfström , E 2019 , ' Tensions and the Teacher's Role in Student Teacher Identity Development in Primary and Subject Teacher Curricula ' , Scandinavian Journal of Educational Research , vol. 63 , no. 5 , pp. 679-695 . https://doi.org/10.1080/00313831.2017.1420688

http://hdl.handle.net/10138/325422

https://doi.org/10.1080/00313831.2017.1420688

unspecified

acceptedVersion

Downloaded from Helda, University of Helsinki institutional repository.

This is an electronic reprint of the original article.

This reprint may differ from the original in pagination and typographic detail.

Please cite the original version. 
To cite, please refer to this article as:

Anspal, T., Leijen, Ä. \& Löfström, E. (2019). Tensions and the teacher's role in student teacher identity development in primary and subject teacher curricula. Scandinavian Journal of Educational Research, 63(5), 679-695.

Tiina Anspal ${ }^{*}, \ddot{A l i}$ Leijen $^{\mathrm{a}}$ and Erika Löfström ${ }^{\mathrm{b}}$

${ }^{a}$ University of Tartu, Estonia, e-mail: ali.leijen@ut.ee

${ }^{\mathrm{b}}$ University of Helsinki, Finland and Tallinn University, Estonia, e-mail: erika.lofstrom@helsinki.fi

*corresponding author. Institute of Education, Faculty of Social Sciences, University of Tartu, Salme 1a, Tartu. 50103.

E-mail address: tiina.anspal@gmail.com

\section{Biographical notes of the authors}

Erika Löfström ( $\mathrm{PhD}$, Educational Sciences) is Vice Rector for Innovation in Education at Tallinn University (Estonia), and Visiting Professor at the School of Educational Sciences, Tallinn University. She also has an affiliation with the University of Helsinki (Finland) as Research Director at the Faculty of Educational Sciences. Her research areas include research ethics and integrity, university pedagogy, and teacher education. She is a board member of the network Teacher Education Policy in Europe, Chair of the Advisory Board on Ethics in Research on Human Participants (University of Helsinki), a member of the Finnish Advisory Board on Research Integrity, and participates in audits of higher education institutions as an expert of the Finnish Education Evaluation Council.

Äli Leijen $(\mathrm{PhD})$ is a Professor of Teacher Education at the Tartu University in Estonia. Her academic background is educational sciences. Her $\mathrm{PhD}$ thesis explored possibilities for innovation and change in arts education. Her current work is mostly focused on teacher education. She leads and participates in several national and international research projects on teacher education. Her current research themes include: teacher knowledge; teacher professional identity; teacher education; reflection in education; ICT for implementing innovations in education. 
Tiina Anspal is a PhD student at the University of Tartu, Faculty of Social Sciences, Estonia. In her research, she focuses on student teachers' professional identity development, exploring links between identity and characteristics of the teacher education program. 


\begin{abstract}
This paper describes a two-year follow-up study on teacher identity development in different types of teacher education programmes. Teacher identity development was analysed with a focus on student teachers' views of teacher's roles and tensions experienced during their studies. Student teachers $(\mathrm{N}=20)$ were interviewed at the beginning and end of the masterlevel studies. Three types of tensions were identified: conception of self versus professional role, role expectations versus university training, and multiple professional role expectations. The follow-up study showed that tensions tended to accumulate to some extent. However, successful consolidation of tensions appeared to depend on how the student teachers were able to recognize resources at their disposal, with implications for organization of reflection support in teacher education.
\end{abstract}

Keywords: teacher identity, teacher education, identity development, tensions 


\section{Introduction}

In recent years, teacher professional identity development has gained increased attention among researchers, especially with the focus on identity development of student teachers (e.g Alsup, 2006, Izadinia, 2013; Lamote \& Engels, 2010; Leijen \& Kullasepp, 2013, Poom-Valickis \& Löfström, 2014) or more generally beginning teachers in their transition time from student to first year teaching (Pillen, Beijaard, \& Brok, 2013a; Pillen, Beijaard, \& Brok, 2013b, Pillen, Brok,\& Beijaard 2013c). Focusing on experienced teachers, Day and his colleagues conclude that teachers' identity is a key factor influencing a teacher's sense of purpose, self-efficacy, motivation, commitment, and effectiveness (Day, Sammons, Stobart, Kington, \& Gu 2007, 103).

The development of teacher identity is, however, a complex process as identity formation has already begun before student teachers enter formal teacher education. Student teachers enter teacher education with prior and internalised beliefs and values about teaching and learning (e.g. Kagan, 1992; Löfström, Poom-Valickis, Hannula, \& Mathews, 2010), and their professional identity continues to develop over the course of their studies and later on while working as teachers. Considering initial teacher education, it has been argued that the learning of student teachers is meaningful only when embedded in the experience of learning to teach and reflecting on this experience, during which the notions of oneself as teacher are shaped (Korthagen, Loughran \& Russell, 2006). Several studies emphasize the importance of designing programmes that allow student teachers to learn and reflect on their teaching experiences from early on in their studies in order to reduce the gap between theory and practice in teacher education programmes (e.g. Grossman, Hammerness, \& McDonald, 2009; Hammerness, 2013; Korthagen et al., 2006). However, teacher education programs are conducted and organized in a variety of ways (see e.g. Zeichner and Conklin, 2005) and it is unclear to what extent different programs address the above described pedagogical principles for teacher identity development. 
The aim of the current study is to identify possible differences between the identity development of primary teachers and subject teachers in the subject and primary teacher curricula. The context of this study is Estonian teacher education, in which primary teachers follow an integrated five-year curriculum resulting in a master's degree. Teaching practice integrated along the entire duration of the programme is thought to bridge the gap between theoretical and practical knowledge. Subject teacher's programmes, however, follow a $3+2$ system, where teacher education is offered at the master's level on top of a bachelor's degree in a subject. Student teachers begin their teacher education with theoretical studies, followed by the main teaching practice in the second year. The differences between the integrated primary teacher education programmes and programmes in the $3+2$ scheme has raised the question of whether subject teacher education sufficiently prepares student teachers for the teacher profession and sufficiently supports student teachers' identity development. It is in this context that the present study sheds light on student teachers preparedness to work in school through their role conceptions and experiences of tensions between various aspects of teacher identity.

\section{Theoretical framework}

\section{Teacher identity}

Teacher identity development is influenced by different factors, such as prior experiences and beliefs, personal biography and personality, motivation to become a teacher, work environment, colleagues, mentors, and emotions (e.g. Beauchamp \& Thomas, 2009; Beijaard, Meijer, \& Verloop, 2004; Flores \& Day, 2006; Rogers \& Scott, 2008; Timoštšuk \& Ugaste, 2010, 2012). Teacher identity is regarded as discontinuous, malleable and shifting (Rogers \& Scott, 2008). In other words, teacher identity is influenced by the interpretation and re-interpretation of experiences (Kerby, 1991). Second, teacher identity develops through social interactions in 
social contexts, including personal biography, previous experiences as a pupil, and teacher education (Flores \& Day, 2006; Rogers \& Scott, 2008). Prior beliefs and knowledge serve as filters through which student teachers experience teacher education (Kagan, 1992; Pajares, 1992). The continuous dialogue between the ideals and the experiences during teacher education, especially during teaching practice, can challenge student teachers' thinking and can thus be useful for their professional identity development (Cattley, 2007). Third, although identity is constantly changing and influenced by different forces, we can apply analytical lenses to distinguish between different perspectives (e.g. Gee, 2000) or dimensions (e.g. Beijaard et al., 2004) of identity which help us to understand the process and important forces within teacher identity development. Gee (2000) differentiated between four ways to view identity: 1) the nature-perspective (N-identity) emphasises the state of a person which is developed by the forces of nature, e.g. being an identical twin; 2) the institutional perspective (I-identity) highlights a position a person has that is authorized by authorities within an institution, e.g. a person is certified to work as a teacher in a school; 3) a discursive perspective (D-identity), which focuses on individual trait(s) of a person that are recognized in the discourse or dialogue by other individuals, e.g. a person is recognized by other teachers as a charismatic speaker and therefore asked to represent a team of teachers. ; and 4) an affinity perspective (Aidentity) that emphasises the shared experiences within an affinity group, e.g. a person belongs to a hobby group and carries out activities with other members of this group. These identities interrelate in complex ways, and certain perspectives are more in the foreground at specific points in the development process. Considering student teacher identity development, we can see that, although alternative views are appearing (see e.g. Alsup, 2006), the institutional perspective is still very influential in supporting the development of occupation- related "professionalism": i.e. through exerting influence on the development of attitudes, skills, and 
knowledge necessary in the teaching profession (see e.g. Berliner, 2001; Krull, Oras, \& Sisask, 2007).

To further conceptualise the I-identity in teaching profession, as presented in Gee's framework, we can utilize the teacher professional identity model by Beijaard, Verloop, and Vermunt (2000). This model distinguishes between different knowledge bases of teacher identity, but we can also utilise the model to understand how student teachers perceive themselves professionally. The knowledge bases, commonly identified in European teaching practice, are expertise in a subject area, didactic and pedagogical expertise, and combinations of these (ibid, 751). Teacher expertise in a subject area includes thorough and deep level of understanding of phenomena in one's field and shows an orientation towards the academic subject. As a pedagogical expert, relationships, values, and the moral and emotional aspects of development are considered to be at the core of the teacher's work. A teacher's expertise in didactics emphasises the teaching of the subject matter using discipline-specific knowledge to facilitate the learning processes of pupils and creating a positive learning environment.

Therefore, we propose that the I-identity in Gee's framework may be further operationalized in teacher identity context by distinguishing between subject knowledge, didactics and pedagogical knowledge.

\section{Tensions}

Previous research has identified a variety of professional identity tensions among student teachers and beginning teachers (e.g. Alsup 2006; Pillen et al., 2013a, 2013b; Leijen \& Kullasepp, 2013). Drawing on the theoretical framework of Gee, Alsup (2006), for example, identifies three types of tensions, which in principle represent tensions between different perspectives of identity: i) the tension between being a student at university studying in a teacher education program and being a teacher at school during pedagogical practice; ii) the 
tension between personal convictions, skills and professional role expectations, and iii) the tension between what is taught at university about teaching and learning and what is experienced at the practice school. Beneath these tensions there may be a mismatch between different forces such as nature, institutions or relational groups that guide certain identity perspective (cf. Gee 2000). Building on Alsup's framework, Leijen and Kullasepp (2013) also identified tensions related to the gap between knowledge about teaching and learning and actual practices in student teachers' practice schools and tensions between the professional role expectations and personal aspects of a student teacher.

Experiencing tensions may be essential for the development of student teachers' and beginning teachers' professional identity (Alsup, 2006; Meijer, de Graaf, \& Meirink., 2011; SchatzOppenheimer \& Dvir, 2014). Studies profiling tensions of beginning teachers' professional identity suggest that tensions change during the transition period from a final year student to newly-qualified working teacher (Pillen et al., 2013c). While tensions are helpful in terms of identity development, some tensions might be too complex to reconcile. These unresolved tensions may contribute to leaving the teaching profession of student teachers (Alsup 2006; Smagorinsky, Cook, Moore, Jackson, \& Fry 2004). Identity tensions have been said to "oppose teachers' feelings, values, beliefs or perceptions" (Pillen et al. 2013a, 662), being contrasted with "typical" beginning teacher problems that beginning teachers usually encounter (e.g classroom discipline, assessing pupils work, individual differences) but what are considered solvable (Veenman, 1984). Tensions are considered broadly in this study including competence gaps, worries, contradictions, and conflicts experienced by student teachers during their studies. Tensions in this study can thus include typical problems(cf. Veenman 1984) as well as identity tensions (cf. Pillen et al 2013c). Tensions, conflicts, and gaps all contribute to the development of a teacher identity and may emerge at the interfaces of perceived present and future selves, 
idealistic images of the teacher and school reality, and personal approaches and social constructions of teacher's role (Schatz-Oppenheimer \& Dvir, 2014).

Although teacher identity has been studied extensively in recent decades, emerging tensions in connection to teacher identity development among student teachers is a relatively new research area (see Pillen, 2013b for an overview). Moreover, although we know from previous studies that teacher specialization is an important factor in identity development (see e.g. Beijaard et al., 2000), mainly general aspects are known about the role of the content and organization of teacher education programs in identity development. For example, prior research in the Estonian context (Anspal, Eisenschmidt, \& Löfström, 2012) identified a process through which primary teachers' identity develops during their five-year studies. The identity of primary teachers develops from ideology and enthusiasm in the first year, to focus on knowledge acquisition and becoming more aware of the job of a teacher in the second and third years, to consolidation of contradictions, and to embracing the anticipated professional role in the fourth and fifth years. The present study focuses more specifically on the nature and dynamics of identity tensions student teachers experience in integrated versus non-integrated teacher education programmes. We examined student teachers' views of teacher role and the tensions that student teachers from different teacher education programmes experience over the course of two years (master's level in teacher education). As we utilise a qualitative approach, our aim is to expose a variety of tensions rather than to identify their frequency or prevalence. In this analysis, we mainly draw on the identity models of Gee (2000) and Beijaard et al. (2000). We posed the following research questions:

1. What kind of tensions do student teachers experience in different types of teacher education curricula and how are these tensions related to how student teachers perceive teacher's roles? 
2. How does the nature of the identity tensions experienced by student teachers change during the two years in the master's level of teacher education in different types of curricula?

\section{Methods}

\section{The context and participants}

Different educational routes can be taken to becoming a teacher in Estonia. Primary teachers follow an integrated five-year primary teacher education programme (PT) in which professional and subject studies take place concurrently. Teaching practice (28 ECTS credits) in the PT programme starts with observation practice in the second year and continues in the $3^{\text {rd }}, 4^{\text {th }}$ year, with the main teaching practice starting in year three. The main teaching practice is divided into two parts: teaching in first through third grade during the third year (11 ECTS), and fourth through sixth grade during the fourth year (11 ECTS). Primary teachers are prepared to teach in grades 1-6.

To become a subject teacher in one subject, a student has to complete a bachelor's degree in that subject, after which he or she may enrol in a master's level teacher education programme (ST). During the time of the data collection, ${ }^{1}$ the teaching practice (15 ECTS credits) of subject teachers was divided into one week of observing classes at the practice schools (observation practice, 3 ECTS) in the first year of master's studies and 10-12 weeks of teaching (main teaching practice, 12 ECTS) during the second year of the studies. Subject teachers are prepared to teach on subject in grades 5-12.

\footnotetext{
${ }^{1}$ During the years 2010-2015, several changes have been made in the teacher education programmes, including changes in the amount and structure of the practice periods during the two-year subject teacher programme. Changes have also been made to the primary teacher programme.
} 
In response to the Bologna process, a multiple subject teachers' programme (MST) was constructed. The MST programme aims to integrate subject studies and pedagogical studies. Teaching practice begins earlier than in the ST programme, while still remaining in the $3+2$ model. The three-year bachelor's programme includes studies in two subject areas, some pedagogical studies and observation practice (3 ECTS) in the third year. The master-level teacher education programme combines the study of a third subject and the study of pedagogy and subject didactics, including main teaching practice (14 ECTS). After graduating from BAlevel subject studies, the graduates may continue studies at the MA level in the MST or the ST programme, or alternatively continue studies in their subject area. Table 1 illustrates the defining characteristics of three types of curricula concerning the length of study and the period of the teaching practice. Multiple subject teachers are prepared to teach up to three subjects in grades 5-9.

Twenty student teachers from a large university in Estonia volunteered to participate in the first data collection. Five of them studied in the PT, 11 in the ST and four in the MST programme. The student teachers were women aged 23-27 years, which is representative of the student population of these programmes. Of the 20 student teachers, 16 participated in the second interview conducted a year and a half after the first interview (all five primary teachers, seven subject teachers, and four multiple subject teachers). To ensure anonymity, pseudonyms are used. 
Table 1. Defining Characteristics of the curricula

\begin{tabular}{|c|c|c|}
\hline $\begin{array}{l}\text { INTEGRATION / SUBJECTS } \\
\text { AND PRACTICE }\end{array}$ & One subject & Several subjects \\
\hline Not integrated $(3+2$ years) & $\begin{array}{l}\text { Subject teacher }(\mathbf{n}=7-11) \text {. } \\
\text { Main teaching practice starts } \\
\text { in the } 2^{\text {nd }} \text { (final) year of the } \\
\text { programme }\end{array}$ & $\begin{array}{l}\text { Multiple subject teacher education } \\
(\mathbf{n}=4) \\
\text { Main teaching practice starts in the } 2^{\text {nd }} \\
\text { (final) year of the programme. In } \\
\text { addition there is observation practice } \\
\text { in the } 3^{\text {rd }} \text { (final) year of BA studies. }\end{array}$ \\
\hline Integrated ( 5 years) & & $\begin{array}{l}\text { Primary teacher education }(\mathbf{n}=\mathbf{5}) \\
\text { Main teaching practice starts in the } 3^{\text {rd }} \\
\text { year of the studies. In addition there is } \\
\text { observation practice in the } 2^{\text {nd }} \text { year of } \\
\text { the studies. }\end{array}$ \\
\hline
\end{tabular}

\section{Data collection}

This study follows a 2-year follow-up design with data collection points in 2011 and 2013. Data collection took place in the two final years of the PT programme and the two years of the ST and MST programme. Participants were recruited through visiting their lectures as well as through mailing lists. Participation was voluntary, and no incentives were offered. Informed consent was sought for both rounds of interviews. Data were gathered using semi-structured interviews conducted by the first author. On average, each interview lasted one hour. The interviewer had no relationship with the interviewees.

The interviews included the following topics: the motivation for becoming a teacher; the view of oneself as a teacher; views of teachers' role; role models; significant learning experiences during studies; future perspectives; and worries and fears related to starting work as teachers. In the second interview, conducted one and a half years after the first, participants were asked to describe themselves as teachers and refer to changes in themselves as teachers that they had perceived since the first interview. 
Student teachers were not explicitly asked about tensions in order to avoid provoking problem descriptions. By asking questions about students' experiences of themselves as prospective teachers, we sought to understand how tensions were embedded in their views of themselves as teachers.

\section{Data analysis}

The data were analysed using thematic analysis, which is 'a method for identifying, analysing and reporting patterns (themes) within data' but which also gives the possibility to provide a detailed account of themes in the data (Braun \& Clarke, 2006, 79). The tension categories "conception of self vs professional role expectations" and "university versus real-life knowledge", as identified in previous studies (Alsup 2006; Leijen, \& Kullasepp 2013), were used as initial sensitizing concepts to provide an indication of the kinds of tensions that may emerge between different identity perspectives as proposed by Gee (2000) (e.g. between Nidentity and I-identity). Beijaard et al.'s (2000) teacher identity model was used as a framework to identify aspects of Gee's institutional identity perspective (variations of I-identity manifested in teacher role as subject specialist, didactic expert, and pedagogue).

Subsequently, the data analysis followed the six phases proposed by Braun and Clarke (2006). First, all the audio-taped interviews were transcribed and the transcripts were read for initial inductive categorisation. The unit of analysis was a whole thought consisting of one or several sentences. Second, meaningful units relevant to the research questions were identified and categorised. At this point we identified tension categories such as: "class discipline", "ideals and practice", "not enough knowledge/skills" and "not enough time", and role categories such as: "subject specialist" and "didactics expert" and role perceptions related to the caring nature and values of a teacher as "pedagogue". Coded items of roles that did not fit into these categories were analysed inductively resulting in the category "personal characteristics". This 
category describes the student teachers' own or ideal teacher's personal characteristics and did not refer to teacher's knowledge base in relation to teaching or students. A similar category of self-referential descriptions has also been identified elsewhere (Leavy, McSorley \& Bote, 2007; Löfström, Anspal, Hannula, \& Poom-Valickis, 2010). As some role perceptions could be interpreted to fit under different categories, the entire interviews were reread to determine the dominant category.

Third, the initial categories were sorted into potential themes during which some subthemes were also identified. Roles and tensions were analysed in parallel from this stage on. First the theme "conception of self versus professional role" was identified in the data with two subthemes. In one subtheme the focus was on the tension between oneself versus the expected role of the teacher, in the other subtheme, between oneself and the teacher role as experienced in a school situation. Our data did not allow us to distinguish $\mathrm{N}$-identity and D-identity, therefore we could not specify whether these tensions are between $\mathrm{N}$ - and I-identity or between D- and I-identity. Consequently, tensions related to the gaps or conflicts between A-identity and I-identity began to emerge as a secondary theme. The difference in knowledge and practices of the affinity group, and the perceived difference between what was taught at the university and expressed as expectations of the roles teacher have to live up to, formed one theme. Within Gee's (2000) framework, we identified the affinity group (A-identity) as the particular school culture with shared practices that student teachers had a need to belong to, but with which they did not necessarily share knowledge and skills allowing them access to full participation. There were two types of competence gaps expressed within this theme that formed two sub-themes; insufficient preparedness for filling teacher's role and problems integrating theoretical knowledge with teaching practice. The third theme included tensions between the different aspects of I-identity - subject specialist, didactics expert, and pedagogue that were closely connected with initial category "not enough time". 
Fourth, the themes were reviewed again to assure their coherence and the labels of all three main themes were established, including the third theme "multiple professional role expectations". Tensions within this theme emphasised the fact that the manifold professional expectations on the teacher's professional role create different discourses, some of which are conflicting and manifest in different aspects of the I-identity. In several cases it was complicated to differentiate between the theme "Conceptions of self" and "Multiple professional role expectations" as tensions in both themes were associated with lack of time and dissatisfaction with oneself as a person/mother/partner. In these cases the whole transcript was read again to form an understanding of the reasons behind the dissatisfaction that characterised the theme.

Fifth, all transcripts were read again. The established themes were viewed against each other in order to establish the uniqueness of the theme and to form a holistic overview of the content that each theme covered compared to other themes. The follow-up data were first analysed separately using the same procedure described above and then compared and analysed together with the data from first interview with the focus of possible changes. The sixth and final phase ended with writing up the three themes pertaining to tensions in teacher identity (see Table 2). 
Table 2. Tensions: themes and subthemes

\begin{tabular}{|c|c|c|c|c|}
\hline Theme & Subthemes & Data expert & $\begin{array}{c}\text { Number of } \\
\text { student } \\
\text { teachers } \\
\text { expressing } \\
\text { tensions in } \\
\text { the } \\
1^{\text {st }} / 2^{\text {nd }} \\
\text { interview }\end{array}$ & $\begin{array}{c}\text { Frequency } \\
\text { of tensions } \\
\text { during the } \\
1^{\text {st }} / 2^{\text {nd }} \\
\text { interview }\end{array}$ \\
\hline \multirow[t]{2}{*}{$\begin{array}{l}1 . \\
\text { Conceptions } \\
\text { of self } \\
\text { versus } \\
\text { professional } \\
\text { role } \\
\text { expectations }\end{array}$} & $\begin{array}{l}\text { Subtheme 1: } \\
\text { Conception of self } \\
\text { versus teacher's } \\
\text { role. The focus is } \\
\text { on the perceptions } \\
\text { of teacher's role } \\
\text { expectation }\end{array}$ & $\begin{array}{l}\text { My personal } \\
\text { characteristics and } \\
\text { conceptions about } \\
\text { teaching and } \\
\text { learning are in } \\
\text { contrast to the } \\
\text { teacher's role }\end{array}$ & $\begin{array}{l}\text { Primary } \\
\text { teachers: } 0 / 0 \\
\text { Subject } \\
\text { teachers: } 6 / 2\end{array}$ & $\begin{array}{l}\text { Primary } \\
\text { teachers: } 0 / 0 \\
\text { Subject } \\
\text { teachers: } 8 / 2\end{array}$ \\
\hline & $\begin{array}{l}\text { Subtheme 2: } \\
\text { Conception of self } \\
\text { versus teacher's } \\
\text { role experienced. } \\
\text { The focus is on the } \\
\text { experience of } \\
\text { teacher's role }\end{array}$ & $\begin{array}{l}\text { experienced or } \\
\text { expected to } \\
\text { experience. } \\
\text { Conflict between my } \\
\text { personal } \\
\text { characteristics, } \\
\text { conceptions, and } \\
\text { role expectations }\end{array}$ & $\begin{array}{l}\text { Primary } \\
\text { teachers: } 3 / 3 \\
\text { Subject } \\
\text { teachers: } 3 / 6\end{array}$ & $\begin{array}{l}\text { Primary } \\
\text { teachers: } \\
13 / 9 \\
\text { Subject } \\
\text { teachers: } \\
6 / 14\end{array}$ \\
\hline $\begin{array}{l}\text { 2. Role } \\
\text { expectations } \\
\text { versus } \\
\text { university } \\
\text { training }\end{array}$ & $\begin{array}{l}\text { Subtheme 1: } \\
\text { Insufficient } \\
\text { preparedness for } \\
\text { teaching that cause } \\
\text { tensions. This } \\
\text { includes not having } \\
\text { enough } \\
\text { knowledge/skills to } \\
\text { be able to deal with }\end{array}$ & $\begin{array}{l}\text { Teachers have to } \\
\text { have a lot of } \\
\text { specific knowledge } \\
\text { and skills to teach } \\
\text { and fit in to the } \\
\text { school culture } \\
\text { (affinity group), but } \\
\text { teacher education } \\
\text { programmes at }\end{array}$ & $\begin{array}{l}\text { Primary } \\
\text { teachers: } 4 / 3 \\
\text { Subject } \\
\text { teachers: } 4 / 7\end{array}$ & $\begin{array}{l}\text { Primary } \\
\text { teachers: } 9 / 3 \\
\text { Subject } \\
\text { teachers: } 5 / 9\end{array}$ \\
\hline
\end{tabular}




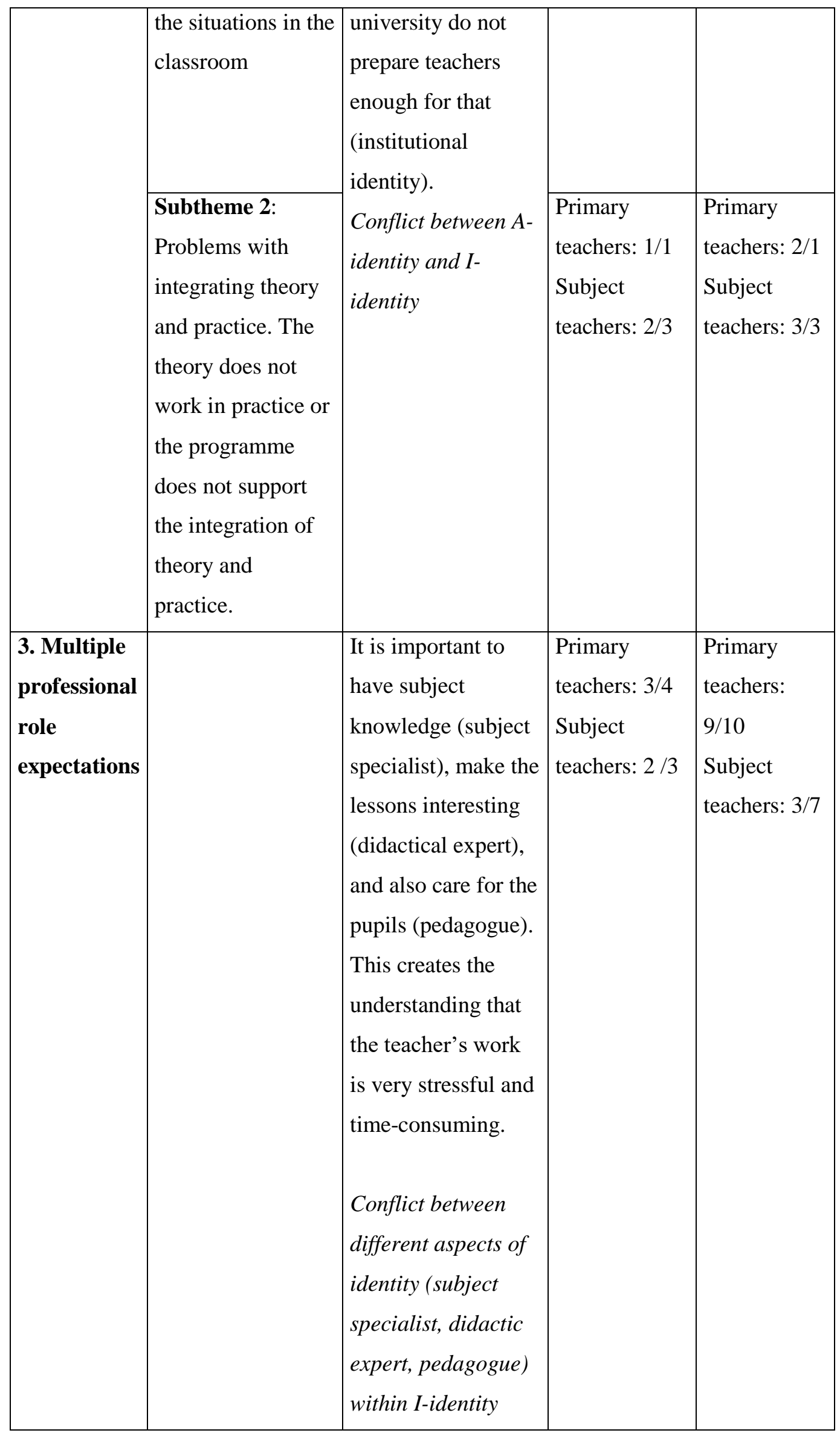


The types of curricula student teachers followed were considered, and students' role conceptions and tensions were compared across the three types of curricula (see Table 1). The main distinguishing characteristics of the curricula were the length and level of integration of teacher education components and teaching practice in the programmes. Another distinguishing element was the number of subjects that the students should be able to teach.

We have provided data excerpts from the interviews to illustrate the categories. Some of the student teachers provided "thicker" descriptions of their tensions. Consequently, these interviews have provided more illustrative and nuanced examples. For instance, one student, Madli, expressed a number of tensions and thus provided a variety of "tensions descriptions", more so than the other students. However, we have utilised excerpts and examples from different students. Data analysis was carried out by the first author using NVivo 10 software, and the interpretations were validated in continuous discussions with all authors. Transcripts were revisited several times during the data analysis. As such, the analysis was an iterative process in which the categories became more distinct with each round of readings. In addition, a case record was also written for each respondent, which included the interview themes that helped to keep a holistic view of each respondent.

\section{Findings}

\section{The nature of the tensions experienced by the student teachers}

Student teachers described themselves as teachers and their experiences through the tensions they experience. Three different themes were identified: 1) conception of self vs professional role expectations; 2) role expectations versus university training; 3) multiple professional role expectations (see Table 2). While focus is on the qualitative nature of the data, we have provided the numbers of student teachers expressing tensions, and the frequency of tensions expressed 
in the first and second interview for the sake of transparency of our categorisation. We discuss these themes from the perspective of differences and similarities in the study programmes.

\section{Conception of self versus professional role}

The tensions in this theme are related to the tension between the conceptions of oneself as a person versus the professional role. However, the sources of these tensions could differ. These tensions typically emerged as a result of one's own teaching experience, during pedagogical practice of not being able to live up to the perceived teacher role expectations (Sub Theme 1). Tensions in this theme also emerged as worries that one's personal conceptions and characteristics might contradict teacher role expectations (Sub Theme 2). Tensions arising from the worry of one's self being conceived of as different from the perceptions of teacher's role were most frequently mentioned by subject teachers during the first interview. These student teachers had no prior teaching experience. Such tensions were not expressed by primary teachers - all of whom already had had practice teaching experience. One multiple subject teacher who experienced tensions between the conception of self and professional role expectations was working as a teacher. In the follow-up interview, however, the tensions expressed by subject teachers emerged in a different way, this time in contrast to experienced role expectations as a result of their own teaching experience during the main teaching practice. Several primary teachers expressed the same type of tensions in both interviews, but there was only one student teacher, Madli, a primary student teacher, who expressed tensions in this domain repeatedly.

Madli strongly expressed the tension between self-conception and role expectations, feeling the need to return to the topic several times during both interviews. Madli perceived a discrepancy between her view of herself as a person and the expectations on her performance in the 
classroom. She imagined that she would have more chances to assume the role of a pedagogue if she just had "a great class and we do everything together". The previous year when she taught during her first teaching practice period in a lower grade class she felt that she had had that kind of experience with her class: the pupils had been pleasant and calm, and she was able to engage the students in a variety of activities in the way she wanted to. She felt capable and the pupils were affectionate towards her. However, her experience teaching $5^{\text {th }}$ grade students in the second teaching practice period was so devastating that she was not able to overcome the experience of failure by the second interview:

"I'm too afraid to start teaching at school; I'm just afraid. Maybe I am selfish or too convenient; I know that in the beginning there will be a heavy workload and you don't know what kind of class you will get and...of course everything can go well. It's not that there are only bad choices, but at the moment I have to say that I'm still afraid." (Madli, PT, II)

Madli's fear seemed to emanate from pupils' disruptive behaviour. She felt that she lacked the knowledge, skills, and confidence to deal with such behaviour and failed to establish authority in the class. Her perceptions of the teacher's role seemed to be formed by her own experiences as a child when she had been afraid of her teacher and she did not want this to happen to anybody else. In her mind, Madli appeared to relate teacher authority with disrespecting students and with being frightening for students. She had observed that other teachers in the practice school sometimes treated pupils with what she interpreted to be disrespect. At the same time, she was criticised by other teachers for being too lenient with pupils who behaved disruptively and was expected to act in a way that was in conflict with her view of the ideal teacher. She was unable to resolve the tensions during her final two years of studies, and decided not to start working as a teacher. Madli followed an integrated 5-year curriculum. Despite the ample time to reflect on and develop teacher identity, the tensions seem to have grown too 
powerful towards the end of the studies for Madli to be able to consolidate the conception of self and of the ideal teacher and the felt expectations from her colleagues into a sufficiently coherent teacher identity.

Liisa, a multiple-subject teacher who was already a practicing teacher working at a school during the first interview, expressed tensions that were connected to a discrepancy between her personal conceptions of the teacher's role and the professional role that the school appeared to emphasise. She expressed profound subject-oriented understanding about the teacher's role, but in her teaching she was confronted with the need to apply more student-centred teaching strategies and didactical knowledge:

\section{"When I was a pupil, I remember that everyone was taking notes and no one complained about it, but now the pupils can't even write two sentences. But, times have changed. I cannot compare myself and I can't compete with other teachers' lessons; no one loves me when everyone else (other teachers) is doing interesting things in their lessons." (Liisa, MST, I)}

Together with low self-efficacy and comparing herself with other teachers, Liisa felt pressure to change herself in order to be perceived of as a "good" teacher who meets pupils' expectations. This created tensions and negative emotions for her during the first interview. However, by the second interview she had gained more experience and confidence as a teacher, emphasizing the role of teaching methods and subject didactics classes she had attended. Observing other teachers helped her understand that teachers rarely meet the ideal and that teachers do make mistakes. This realisation allowed her to gain more respect for herself as a teacher, and made her reflect on her beliefs about teaching. This in turn created a positive feed forward loop further strengthening her self-respect and giving her assurance to continue teaching. For Liisa, combining studies (including teaching practice) with working as a teacher was important in 
order to allow her to develop as a teacher and to consolidate the tensions she experienced. While Liisa had two years to work out any tensions into a sufficiently consolidated understanding, she appeared to manage well in this development task. The key appears to be in the way she recognises and utilises the resources available around her. She makes use of the pedagogical and didactical elements in the teacher education, even though they enter her training at the point in the studies where she has already formed a strong subject identity and she must find a way to bring the other elements of I-identity up to date alongside the belief of the teacher as a subject knowledge expert. Liisa's and Madli's cases demonstrate that while time may be a crucial element in maturing as a teacher, this is not the only influence on that process. Reflection and exploitation of resources appears to play a major role. It is also possible that as a student teacher of multiple subjects Liisa reflected on her experiences across the subjects helping her to recognise specific didactical features in each subject thus facilitating the process of reaching insights related to didactics and pedagogy.

\section{Role expectations versus university training}

Tensions in role expectations versus university training were related to the mismatch between the gained understanding of teachers' role during studies (considered as I-identity) and the practices expected or needed to carry out in teaching practice at schools (A-identity).

Student teachers in different programmes expressed different tensions between role expectation and university training. Tensions were again connected to how student teachers viewed their role as a teacher and the knowledge base that they experienced as necessary for fulfilling that role. Relying on their studies at the university, the student teachers initially felt prepared to fulfil the roles, but as they started teaching, they identified gaps in their competences. The reliance on their competence base and the subsequent realisation of competence gaps created 
tensions for them. Consequently, almost all primary teachers were concerned about their lack of subject knowledge (the first sub-theme) to be able to fulfil the role as a primary teacher. The following example illustrates this experience:

"Science is the worst; this seems to be most complicated. It is easier in first grades, but in fifth grade it's so complicated... you can teach what is there in the textbooks, but you are not able to say anything beyond it." (Kersti, PT, I)

Although primary teachers expressed joy in their interaction with pupils, their worries about the lack of subject knowledge remained throughout both interviews. However, these were expressed less at the time of the second interview, indicating that through time and practical experiences these worries might resolve. These students may have recognised that they lack sufficient subject knowledge competences providing an incentive to work on this area of competences during the last year of teacher education. According to some students, the help of their mentor and gaining more experience throughout the programme helped them to overcome this tension. Problems with lack of subject knowledge were only mentioned by one multiplesubject teacher Liisa, who was working as a teacher, teaching several subjects and classes.

In turn, almost half of the subject teachers mentioned during the second interview that they did not feel sufficiently ready in areas connected with the didactical expert role of a teacher, including assessing student work, facilitating students' independent study, dealing with disruptive behaviour, choosing the right teaching methods or long-term curriculum planning. The role of the teacher as pedagogue was mentioned less. These student teachers also acknowledged that the difficulties occurred because they had little teaching practice and they felt insecure. This might indicate that although subject teachers feel confident about the subject, they need more time in order to connect their didactical, pedagogical and subject area competences than the duration of the programme allows. 


\section{Multiple professional role expectations}

Student teachers' growing understanding of the multiple professional role expectations created tensions accompanied with negative feelings and stress. Confronted with the need to integrate different aspects of teacher I-identity, namely didactic expert, subject specialist, and pedagogue, student teachers experienced a lack of resources for doing that. Most primary teachers expressed this tension during both interviews, while only some subject teachers expressed this tension; mainly in the first interview. All teachers who mentioned the multiple professional role tension seemed to be strongly affected by it, as they referred to this type of tension several times during the interview.

The lack of time was a recurring tension within this theme. The student teachers' felt lack of time to prepare lessons may originate from their need to feel thoroughly prepared for each lesson. These student teachers expressed a lack of confidence in their knowledge and planning of lessons. The perceived pressure to use a substantial amount of time for preparation may have led them to feel that teaching is an all-consuming job that does not leave any time and energy for other areas in life, e.g. one's private life. Alternatively, they may have felt that they sacrifice their ideal teacher identity of being pupil-centred teachers because they failed to prepare their classes that way, ending up settling for teacher-centred approaches to teaching. Some student teachers who expressed these tensions suggested that simply allocating less time for preparing lessons may be one solution to this problem. For example, Kersti, a primary teacher described the ideal teacher and her ideal self as a teacher who makes each lesson interesting and not someone who teaches by the book and lacks creativity. She felt that preparing lessons the way she wished was too energy and time consuming, and she questioned whether it was worth the 
effort. Despite the fact that she continued to prepare her lessons carefully, she was tempted to compromise her ideals as a way to ease the tension, at least temporarily:

"There are those workbooks, and then I read them and think that I don't want to do only these; I want to prepare something else, but this takes so much time and sometimes I feel that I don't want to. Let's just have this lesson like that (with workbook) and go home." (Kersti, PT, I)

While primary teachers were concerned with the lack of subject knowledge, for Kati, a subject teacher this tension meant diverting away from the subject she intended to teach in order to assume appropriate roles for the education of values and the moral upbringing of the children. She had not realised how she could fulfil these additional role demands within the framework of teaching her subject:

\section{"I had not considered that I would have to do other things there in addition to my subject, like teach them values, norms. But, it's just that there are so many other roles teachers have to fulfil apart from just teaching their subject.” (Kati, ST, I)}

Subject teachers have had time during their BA studies to master the subject knowledge in one subject but instead of having the opportunity to deepen subject knowledge and related competences in one or two subjects, primary teachers need to master a broad selection of subjects and subject didactics. As the students will not have the opportunities to go to depth with their studies on different subjects, they may end up with a sense of inadequate preparation.

Several tensions related to multiple professional role expectations were connected to the heavy workload during teaching practice when the student role becomes an additional role with its own obligations. The need to write practice logs and prepare detailed lesson plans for each lesson during the teaching practice created additional stress for some student teachers, especially for the more experienced student teachers (e.g. primary teachers near the end of their 
teaching practice or who already worked as teachers). For example, Mai found this to be an additional workload on top of spending a substantial amount of time preparing for the lessons:

"I really think that if you want a really good lesson plan, it takes 3-4 hours per lesson, or even more. It seems a small task to find information, but it takes so much time. Then you prepare that lesson and later on you have to spend even more time preparing the detailed lesson plan for the practice log. That's about 60 lessons, which is a lot." (Mai, PT, I)

Mai as well as her Triin, another primary teacher, was of the opinion that the detailed lesson plans did not help them and considered them just another add-on increasing the already heavy workload. A similar view was held by one student from ST programme and one from MST programme who were working as teachers outside the programme and felt already relatively confident in the classroom. However, preparing detailed lesson plans was also mentioned by student teachers who had not been teaching before as a helpful way in preparing for the lessons that makes one feel more confident as a teacher. In such cases, careful planning alleviated rather than created stress.

Perceived insufficiencies in fulfilling the role of the ideal teacher were expressed as issues of time pressure that left less time for family and friends. Interviewees voiced doubts about their ability to keep up with intense schedules when working in the profession. There were also suggestions to resolve the issue by starting working as a part-time teacher. Self-reported time pressures may not always correspond with the actual workload, but can be a way of rationalising self-perceived insufficiencies. However, perceived time pressure and dealing with multiple role expectations as a teacher in connection to other challenges seemed to create discouraging tensions that were not resolved by the end of the studies. 


\section{Changes in tensions during the master's level of teacher education}

The tensions experienced by student teachers seemed to have changed over the two year period (Table 2), suggesting differences between study programmes as well as between individuals within a programme.

At the beginning of their master's studies, subject teachers seemed to experience fewer tensions than primary student teachers in all themes, with the exception of their worries that their perceived role as a teacher might be different from their personal characteristics and conceptions of teaching. Most subject teachers expressed no tensions in other themes during the first interview.

At the end of their studies, the frequency and types of tensions that the student teachers experience seemed to have changed. At this point, subject teachers experienced an increase in tensions, especially regarding role expectations versus university training. The relatively low frequency of tensions during the first data collection seemed to be connected with the lack of teaching experience. After teaching practice, student teachers' initial worries that their personality and role expectations may differ were either alleviated or amplified. For example, Paula, a subject teacher, appeared to rely on her prior beliefs about the "good teacher" before teaching practice. She was idealistic and hopeful that she would be able to be the teacher she would like to be. She did not express any doubts or concerns about her ability to assume this role:

"Who I would like to be...that democratic teacher I described earlier. I imagine I could be quite tough, but fair. I'm not sure. I guess one imagines some good teacher one had and tries to be like him or her." (Paula, ST, I)

After the teaching practice, Paula started to understand the complexity of the teaching profession. Paula started to gain a deeper understanding of the teacher's work and she felt that 
it demanded too much investment from her and the subject area she embraced was not the main focus in the lessons.

Tensions expressed by primary teachers during the two final years of their studies seemed to have diminished, except for tensions related to multiple professional role expectations. Almost all primary teachers expressed some tensions in this theme. However, there were two individuals, Elsa and Madli, who reported the majority of the tensions in this theme. Elsa expressed few tensions during the first interview, but during the time of the second interview she started working with pupils with special needs, and she found it difficult to manage. She felt that she had so many roles as a teacher and living up to the expectations associated with each of these roles was too demanding a task:

"Now that I have been teaching, I can see that the teacher has so many roles, in the sense that you are not only a teacher. In addition, you deal with relationships with pupils and solving problems. This is the hardest task at the moment.” (Elsa, PT, II)

In contrast to Madli, Elsa was not planning to quit, indicating the importance of the personality in experiencing tensions. Elsa expressed many tensions in almost all themes, but she found strength from her good relationship with the pupils and the progress she made with the pupils with special needs. She also found the school management supportive and encouraging. It appears that the type of programme was not the main aspect influencing students' choice to continue or terminate their studies. Rather, students' ability to recognise the resources at their disposal and ability to make use of these resources in addition to personality-related aspects appear to have had a more substantial influence on the students' choices. In this sense, Elsa and Liisa, a multiple subject teacher mentioned earlier, utilised similar strategies to overcome tensions despite studying in programmes of different length. 
Tensions connected with experiences of not being sufficiently prepared for teaching and difficulties integrating theory and practice were expressed less during the second interview by the primary teachers, indicating that these might be resolved with teaching experiences. However, as Elsa's case showed, challenging contexts might provoke these tensions to resurface.

Across the different study programmes, students expressing the wish to not start working as teachers or being unsure about entering the teaching profession expressed more tensions and in a greater variety of domains compared to their peers who wished to remain in the profession.

A striking observation was that several subject teachers expressed in general few or no tensions during the first and also the second interview. These student teachers typically had their practice period in selective schools or in schools with a supportive school culture. They tended to express satisfaction with their teaching practice and the support they received. For subject teachers, especially, this implied that they were able to concentrate on teaching their subject.

\section{Discussion and implications}

This study contributes to the understanding of how student teachers experience role conflicts and tensions during teacher education. We also identified possible differences between programmes and changes in the tensions during the two years of teacher education at master's level. While a successful transfer from being a student teacher to a newly qualified teacher is the sum of study and work experiences, and personality, our study shows that the students' ability to handle and learn from various tensions may play a crucial role in teacher identity development. This ability may be detached from the type of programme one studies in.

\section{Types of tensions}


We identified three main types of tensions that emerged as themes from our analysis and show the conflicts between different views and aspects of teacher identity. These were: a) tensions between conceptions of self and professional role expectations, b) role expectations versus university training (tensions between I-identity and A-identity and c) multiple professional role expectations (tensions within I-identity)(Gee 2000). Prior research has identified tensions related to the reconciliation of personal and professional aspects in becoming a teacher (Alsup, 2006), but also tensions related to experiencing the gap between theoretical knowledge and their preparation and practice experiences (e.g. Alsup, 2006; Pillen et al., 2013b; Leijen \& Kullasepp, 2013). In addition, multiple professional role expectations identified in this study, reflects student teachers' experiences of how all-consuming the role of a teacher is, simultaneously imposing on I-identities through the expectation of the teacher being a didactics expert, subject specialist, and a pedagogue (cf. Beijaard et al., 2000) at the same time. What differentiates tensions in role expectations versus university training and multiple professional role expectations was the stress and negative feelings associated with the perceived lack of resources to deal with the tensions when exposed to multiple professional role expectations.

Tensions related to Role expectation versus university training illustrate that student teachers may lack confidence as they begin their teaching practice. The perceived gap between theory and practice has been identified in prior literature, indicating that school conditions are important factors in contributing to beginning teachers' development and learning (Andersson \& Andersson, 2006; Flores, 2001; Flores \& Day, 2006; Geijsel \& Meijers, 2005). Our study offers additional support to the evidence presented in previous research (Alsup, 2006; Leijen \& Kullasepp, 2013) showing that tensions connected to the theory-practice gap are important in the context of teacher identity development during teacher education. While student teachers referred to their lack of competences and skills regarding the role of the pedagogue, didactics 
expert or subject expert they hardly conceptualised these beyond the classroom as aspects of A-identity. When student teachers start working as teachers they should be able to identify themselves as part of the school community. While this appears to gain less attention in preservice teacher education, there is increased pressure on the quality of induction year support.

All three themes of tensions in this study are to some extent related to the lack of "tools" a teacher has - knowledge, skills, competences. This perceived lack might be a minor tension for a student and with enough resources available (support, time, energy, etc.) they might be conceptualised as solvable. The perceived lack of time for private life and family was discussed in connection with tensions within the different aspects of I-identity. Not having enough time for family and friends has been considered a severe contributor to identity tensions (Pillen et al., 2013b). Our study indicates that the multiple role tensions and the perceived lack of knowledge and skills may perceived by student teachers as an unsolvable combination. It is important to address tensions early on in teacher education, as they may accumulate when not acknowledged and reflected on adequately. The teaching practice period offers ample opportunity to explore and address tensions. Almost all primary teachers, but also subject teachers, experienced tensions of this kind.

Our study suggests that student teachers following different types of curricula are likely to emphasise different aspects of the teacher role and associated ideals and consequently experience tensions differently. Primary teachers in our study emphasised creating a good atmosphere and subject knowledge as important means for pupils' development. Subject teachers emphasised good subject knowledge and making the subject interesting. Consequently, the tensions the primary teachers experienced were mostly related to the aspect of I-identity they had not paid enough attention to - their perceived lack of subject knowledge. Subject teachers' tensions appeared to be related to the challenges of adapting their teaching methods 
for the different age groups and pupils, which was found to be difficult and undermined their confidence as pedagogues. Despite differences between tensions experienced in different types of curricula, it is important to recognise that there are also differences between the student teachers within a study programme. Therefore, there is a need for individualised support through mentoring. Gaining empowering experiences is crucial for building confidence as a teacher. It is also necessary to bear in mind that we may not exclude the influence of personality and prior life experiences alongside the study-related experiences, and these remain topics for further research.

\section{Changes in tensions during the two years of study}

Our findings that teaching practice brings out the most tensions, and that student teachers did not experience tensions to any great extent before the practice, are in line with previous research that highlights the role of teaching practice in teacher learning and identity development (Kagan, 1992; Lamote \& Engels, 2010). Our study also indicated that it is in particular the teaching experience that provokes tensions among subject student teachers.

Student teachers in this study referred to the teaching practice as a very intensive period during which they had no time for anything other than preparing and giving lessons. The perceived high workload during practice raises questions of whether student teachers are able to reflect on their experiences connect theory with practice to learn and develop further, or whether teaching practice is just a place to practice teaching without really being challenged to reflect (cf. Gale \& Jackson, 1997). While reflection is considered critical in the development of professional identity, systematic reflection has been found to be difficult for student teachers (Gale \& Jackson, 1997; Korthagen \& Vasalos, 2005; Sutherland, Howard, \& Markauskaite, 2010). There might be a better way to support identity development through practice periods that offer possibilities for actual teaching early on in the programme as opposed to only 
observing classes with mentor support along with special time for reflection and encouraging critical discussions (see also Leijen \& Kullasepp, 2013; Leijen, Kullasepp, \& Anspal, 2014).

Tensions between professional and personal sides of being a teacher have been considered difficult to resolve (Alsup, 2006; Volkmann \& Anderson, 1998). The subject teachers participating in our study, in particular, showed increased tensions between personal and professional aspects of identity after teaching practice. This might be the result of the shorter timeframe of the subject teacher curriculum within which teacher identity must develop and mature. There were also student teachers who experienced hardly any tensions. There may be different reasons why tensions do not emerge. A lack of tensions might indicate that there are sufficient support structures in place, including mentors and peers, who help the student teachers to reconcile different aspects of identity and resolve the tensions that might occur. Student teachers benefit from having trusting relationships with their mentors and support from family (Geijsel \& Meijers, 2005). Another reason might be that student teachers who had their teaching practice at schools selective in terms of their student population, acknowledged that their practice did not require too much class management. Confronted with challenges, newlyqualified teachers might lack the knowledge and strategies of how to cope with challenges because they have had few or no previous experiences.

\section{Limitations and directions for future research}

While the results of the study were not intended to and cannot be generalised, the experiences of the student teachers do portray a variety of role conceptions and tensions shedding light on the dynamic nature of tensions during a two-year period. However, with another sample, additional role conceptions and tensions may emerge. The sample was self-selected, and the student teachers who chose to participate may have had different experiences compared to those 
who did not participate. Furthermore, students differ in how readily they discuss personallyheld beliefs and conceptions, and how willingly they expose tensions. Some students may have found it difficult to discuss these issues, and therefore, provided a restricted view into their experiences. This, however, may not necessarily mean that their identity process was without tensions.

The study provides some suggestions of how the teacher education programme might influence the emergence and handling of tensions. While one may not draw far-reaching conclusions about the impact of the length and level of theory and practice-integration, the results do provide an incentive for investigating further how dealing with tensions related experienced lack of pedagogy and subject matter knowledge could be better built into primary vis-à-vis subject teacher education programmes. We also propose that future research might follow student teachers during the whole study period and focus on the support structure and possible reasons behind the tensions. These studies might benefit from mixed-methods designs. Instead of relying on self-reported data, observing the classes as well as adding practice school variables would be useful.

The student teachers mentioned pupils as a source of major positive emotions, which has been shown to be a major source of teacher satisfaction (cf. Poulou, 2007, Timoštšuk, \& Ugaste, 2012). Future studies focusing on differences between the teacher education programmes should investigate the role of emotions, personal biography, and relationships with pupils in solving tensions. It would also be beneficial for the understanding of tensions in the teaching profession to follow teachers into their in-service years to map out how the tensions change with increasing teaching experience.

\section{Acknowledgements}


This research was supported by the Estonian Science Foundation (No ETF9221) and the European Social Fund. The authors thank the student teachers who participated in the study.

\section{References}

Alsup, J. (2006). Teacher identity discourses: Negotiating personal and professional spaces. New Jersey: Lawrence Erlbaum Associates, Inc.

Andersson, I. \& Andersson, S.B. (2008). Conditions for boundary crossing: Social practices of newly qualified swedish teachers. Scandinavian Journal of Educational Research, 52(6), 643-660.

Anspal, T., Eisenschmidt, E., \& Löfström, E. (2012). Finding myself as a teacher: Exploring the shaping of teacher identities through student teachers' narratives. Teachers and Teaching: Theory and Practice, 18(2), 197-216.

Beauchamp, C., \& Thomas, L. (2009). Understanding teacher identity: An overview of issues in the literature and implications for teacher education. Cambridge Journal of Education, 39(2), 175-189.

Beijaard, D., Verloop, N., \& Vermunt, J. (2000). Teachers' perceptions of professional identity: An exploratory study from a personal knowledge perspective. Teaching and Teacher Education, 16(7), 749-764.

Beijaard, D., Meijer, P. C., \& N. Verloop. (2004). Reconsidering research on teachers' professional identity. Teaching and Teacher Education, 20, 107-128. 
Berliner, D. (2001). Learning about and learning from teachers. International Journal of Educational Research, 35, 463-482.

Braun, V., \& Clarke, V. (2006). Using thematic analysis in psychology. Qualitative Research in Psychology, 3(2), 77-101.

Cattley, G. (2007). Emergence of the professional identity for the pre-service teacher. International Education Journal, 8(2), 337-347.

Day, C., Sammons, P., Stobart, G., Kington, A., \& Gu, Q. (2007). Teachers matter. Connecting work, lives and effectiveness. Berkshire: Open University Press.

Flores, M.A., \& Day, C. (2006). Contexts which shape and reshape new teachers' identities: A multi-perspective study. Teaching and Teacher Education, 22(2), 219-232.

Flores, M.A (2001). Person and context in becoming a new teacher. Journal of Education for Teaching, 27, 135-148.

Gale, T., \& Jackson, C. (1997). Preparing professionals: Student teachers and their supervisors at work. Asia-Pacific Journal of Teacher Education, 25(2), 177-191.

Gee, J.P. (2000). Identity as an analytical lens for research in education. Review of Research in Education, 25, 99-125.

Geijsel, F., \& Meijers, F. (2005). Identity learning: The core process of educational change. Educational Studies, 31, 419-430.

Grossman, P., Hammerness, K., \& McDonald, M. (2009). Redefining teaching, re-imagining teacher education. Teachers and Teaching: Theory and Practice, 15(2), 273-289.

Hammerness, K. (2013). Examining features of teacher education in Norway. Scandinavian Journal of Educational Research, 57(4), 400-419. 
Izadinia, M. (2013). A review of research on student teachers' professional identity. British Educational Research Journal, 39, 694-713.

Kagan, D.M. (1992). Professional growth among preservice and beginning teachers. Review of Educational Research, 62(2), 129-169.

Kerby, A. (1991). Narrative and the self. Bloomington, IN: Indiana University Press.

Korthagen, F., Loughran, J., \& Russell, T. (2006). Developing fundamental principles for teacher education programs and practices. Teaching and Teacher Education, 22(8), 10201041.

Korthagen, F., \& Vasalos, A. (2005). Levels in reflection: Core reflection as a means to enhance professional growth. Teachers and Teaching: Theory and Practice, 11(1), 47-71.

Krull, E., Oras, K. \& Sisask, S. (2007). Differences in teachers' comments on classroom events as indicators of their professional development. Teaching and Teacher Education, 23, 1038-1050.

Lamote, C., \& Engels, N. (2010). The development of student teachers' professional identity. European Journal of Teacher Education, 33(1), 3-18.

Leavy, A. M, McSorley, F.A., \& Bote, L.A. (2007). An examination of what metaphor construction reveals about evolution of preservice teachers beliefs about teaching and learning. Teaching and Teacher Education, 23, 1217-1233.

Leijen, Ä., \& Kullasepp, K. (2013). Unlocking the potential of conflicts: A pilot study of professional identity development facilitation during initial teacher education. International Journal for Dialogical Science, 7(1), 67-86. 
Leijen, Ä., Kullasepp, K.,\& Anspal, T (2014). Pedagogies of developing teacher identity. In C. Craig and L. Orland-Barak (Eds). International Teacher Education: Promising Pedagogies (Part A), (pp. 311-328). Bingley, UK: Emerald Group Publishing Limited.

Löfström, E., Anspal, T., Hannula, M.S., \& Poom-Valickis, K. (2010). Metaphors about 'the teacher': Gendered, discipline-specific and persistent? In Mikk, J., Veisson, M., Luik.P. (Eds.). Teacher's Personality and Professionalism (pp.105 - 122). Frankfurt am Main: Peter Lang Publishers House.

Löfström, E., Poom-Valickis, K., Hannula, M. \& Mathews, S. (2010). Supporting emerging teacher identities: can we identify teacher potential among students? European Journal of Teacher Education, 33, 167-184.

Meijer, P. C., de Graaf, G., \& Meirink, J. (2011). Key experiences in student teachers' development. Teachers and Teaching: Theory and Practice, 17, 115-119.

Pajares, M.F. (1992). Teachers' beliefs and Educational Research: Cleaning up a messy construct. Review of Educational Research, 62(3), 307-332.

Pillen, M., Beijaard, D., \& Brok, P.Den. (2013a). Professional identity tensions of beginning teachers. Teachers and Teaching: Theory and Practice, 19, 660-678.

Pillen, M., Beijaard, D., \& Brok, P.Den. (2013b). Tensions in beginning teachers’ professional development, accompanying feelings and coping strategies. European Journal of Teacher Education, 36, 240-260.

Pillen, M., Brok, P.Den., \& Beijaard, D. (2013c). Profiles and change in beginning teachers' professional identity tensions. Teaching and Teacher Education, 34, 86-97. 
Poom-Valickis, K., Löfström, E. (2014). Pikiuuring õpetajaks õppijate professionaalse identiteedi kujunemisest. [A longitudinal study of the development of the professional identity of student teachers]. Eesti Haridusteaduste Ajakiri, 2(1), 241-271.

Poulou, M. (2007). Student teachers' concerns about teaching practice. European Journal of Teacher Education, 30(1), 91-110.

Rodgers, C., \& Scott, K. (2008). The development of the personal self and professional identity in learning to teach. In M. Cochran-Smith, S. Feiman-Nemser, D.J. McIntyre \& K.E. Demers (Eds.), Handbook of research on teacher education: Enduring questions and changing contexts (pp.732-755). New York: Routledge.

Schatz-Oppenheimer, O., \& Dvir, N. (2014). From ugly duckling to swan: stories of novice teachers. Teaching and Teacher Education, 37, 140-149.

Smagorinsky, P., Cook, L. S., Moore, C., Jackson, A. Y., \& Fry, P.G. (2004). Tensions in learning to teach: Accommodation and the development of a teaching identity. Journal of Teacher Education, 55, 8-24.

Sutherland, L., Howard, S., \& Markauskaite, L. (2010). Professional identity creation: Examining the development of beginning preservice teachers' understanding of their work as teachers. Teaching and Teacher Education, 26, 455-465.

Timoštsuk, I., \& Ugaste, A. (2012). The role of emotions in student teachers identity. European Journal of Teacher Education, 35 (4), 421-433.

Timoštšuk, I., \& Ugaste, A. (2010). Student teachers' professional identity. Teaching and Teacher Education, 26 (8), 1563-1570. 
Veenman, S. (1984). Perceived problems of beginning teachers. Review of Educational Research, 54(2), 143-178.

Volkmann, M. J., \& M. A. Anderson (1998). Creating professional identity: Dilemmas and metaphors of a first-year chemistry teacher. Science Education, 82(3), 293-31

Zeichner, K.M., \& Conklin, H.G. (2005). Teacher education programs. In M. Cohran-Smith \& K. Zeichner (Eds.). Studying teacher education: the report of the AERA panel on research and teacher education. (pp. 645-735). Mahwah, NJ: Lawrence Erlbaum. 
